\title{
Students' Perceptions of the Goal Structure in Mathematics Classrooms: Relations with Goal Orientations, Mathematics Anxiety, and Help-Seeking Behavior
}

\author{
Roger A. Federici ${ }^{1}$, Einar M. Skaalvik ${ }^{1} \&$ Truls N. Tangen ${ }^{1}$ \\ ${ }^{1}$ Department of Education, Norwegian University of Science and Technology, Trondheim, Norway \\ Correspondence: Roger A. Federici, Department of Education, Norwegian University of Science and Technology, \\ 7491 Trondheim, Norway. Tel: 47-9593-6231. E-mail: roger.federici@ntnu.no
}

Received: October 10, 2014 Accepted: November 20, 2014 Online Published: February 25, 2015

doi:10.5539/ies.v8n3p146 URL: http://dx.doi.org/10.5539/ies.v8n3p146

\begin{abstract}
This study explores relations between students' perceptions of the classroom goal structures, their personal goal orientations, mathematics anxiety, and help-seeking behavior in mathematics classes. The respondents were 309 Norwegian middle school students. The data were analyzed by means of structural equation modeling (SEM). The analyses revealed that a mastery goal orientation was associated with lower levels of anxiety and more use of help-seeking behavior whereas performance-avoidance orientation predicted higher levels of anxiety and less use of help-seeking behavior. We found no direct relation between goal structure and mathematics anxiety or help-seeking behavior. However, the perceived goal structure was indirectly related to these variables, mediated through personal goal orientation.
\end{abstract}

Keywords: classroom goal structure, students' goal orientation, mathematics anxiety, help-seeking behavior

\section{Introduction}

Both teachers and students receive mixed signals about what is most important in school. For instance, E. Skaalvik and S. Skaalvik (2013a) found large variations between teachers when they explained how they knew if they did a good job, indicating important differences in their perceptions of goals and values in school. These contradictory signals may have implications for both teachers' instructional practices and students' perceptions of the learning environment at school. One prominent framework for analyzing which signals are received, in our case by the students, is achievement goal theory.

According to achievement goal theory students engage in schoolwork for different reasons. They also have different reasons for showing low involvement in schoolwork (e.g., Ames, 1992; Patrick, Kaplan, \& Ryan, 2011). Three subtypes of reasons or goal orientations have typically been explored: mastery orientation, performance-approach orientation, and performance-avoidance orientation (e.g., Skaalvik, 1997; Walker, 2012). Research consistently shows that students' goal orientations are associated with a number of emotional and behavioral outcomes as well as student achievement (Meece, Anderman, \& Anderman, 2006).

An assumption in achievement goal theory is that classroom characteristics influence students' goal orientations. One such characteristic emphasized in achievement goal theory is the classroom goal structure. Goal structure refers to the type of achievement goals emphasized by the current educational practices within a learning environment (Wolters, 2004). Contemporary research has been concerned with two dimensions of goal structures: a mastery goal structure emphasizing the development of competence and a performance goal structure emphasizing the demonstration of competence (Patrick, et al., 2011). Previous studies clearly indicate that the classroom goal structure is related to student motivation, including goal orientation (e.g., Karabenick, 2004; Meier, Reindl, Grassinger, et al., 2013; Nolen \& Haladyna, 1990; Polychroni, Hatzichristou, \& Sideridis, 2012; E. Skaalvik \& S. Skaalvik, 2013b; Walker, 2012; Wolters, 2004).

This study explores relations between students' perceptions of the mathematics classroom goal structure, students' personal goal orientations in mathematics classes, mathematics anxiety, and help-seeking behavior in mathematics lessons. An important research question for the study was whether and to what degree the relations between classroom goal structures and students' mathematics anxiety and help-seeking behavior are mediated through their personal goal orientations. 


\section{Theoretical Perspectives}

\subsection{Goal Structure}

In research on goal structure a distinction is made between a mastery and a performance goal structure (Ames, 1992; Meece et al., 2006; Patrick et al., 2011). A mastery goal structure is characterized by an environment where teachers focus on student effort, emphasize understanding, and value improvement. Doing mistakes are regarded as being a natural part of the learning process. In such classrooms, teachers promote self-referenced judgments of abilities and success is defined as individual improvement (Sproule, Wang, Morgan, McNeill, \& McMorris, 2007; Urdan \& Schoenfelder, 2006; Urdan \& Turner, 2005).According to Ames (1992) a mastery goal structure is characterized by a set of practices. Practices often emphasized in goal theory are: focusing on meaningful aspects of the learning activities, designing tasks for novelty, variety, diversity, and interest, designing tasks that offer reasonable challenges to individual students, providing opportunities for students to have some choice and control over the activities in the classroom, helping students set personal and short term goals, making evaluation private, not public, and recognizing effort, goal attainment, and individual improvement when evaluating students' work (e.g., Ames, 1992). In contrast, a performance goal structure is associated with the public display of grades, an emphasis on standardized test scores, and comparison of results between schools, classes, or students. Such environments define success as outperforming others or surpassing normative standards (Patrick et al., 2011).

Research reveals that perception of a mastery goal structure is associated with adaptive cognitive, emotional, and behavioral beliefs and responses; for instance the feeling of belonging (Walker, 2012), positive relations with teachers and peers (Polychroni et al., 2012; E. Skaalvik \& S. Skaalvik, 2013b), increased likelihood for accepting challenging tasks (Ames \& Archer, 1988), adaptive learning strategies (Nolen \& Haladyna, 1990), help-seeking behavior (Butler \& Shibaz, 2008; Karabenick, 2004; E. Skaalvik \& S. Skaalvik, 2013b), greater effort, intrinsic motivation, and persistence (E. Skaalvik \& S. Skaalvik, 2013b; Wolters, 2004). In contrast, research indicates that a performance goal structure is associated with less adaptive beliefs and responses. For instance, Polychroni et al. (2012) found less positive relations with peers and teachers. Also, findings reveal that a performance goal structure is negatively related to help-seeking behavior (Karabenick, 2004) and persistence (Wolters, 2004), whereas it is positively related to procrastination and self-handicapping (Urdan, 2004; Wolters, 2004) and to mathematics anxiety (Lavasani, Hejazi, \& Varzaneh, 2011).

It is important to note that even though goal structure is communicated through educational and instructional practices at schools, it is how the individual student perceives the goal structure that influence his or her responses (Meece et al., 2006).

\subsection{Goal Orientation}

Achievement goal orientation may be conceptualized as individual student's reasons for achievement behavior (Ames, 1992; Patrick, et al., 2011; Wolters, 2004). This theoretical framework suggests that students have different reasons for engaging or not engaging in learning activities but also different standards for evaluating the outcome of learning activities (Ames, 1992; Urdan \& Turner, 2005).Research provides strong evidence that students' achievement goal orientations are affected by the goal structure in the classroom or school (e.g., Luo, Hogan, \& Paris, 2011; Roeser, Midgley, \& Urdan, 1996; Urdan \& Midgley, 2003; Wolters, 2004).

Until 1996/1997 the research on goal theory focused primarily on two goal perspectives: mastery goals and performance goals (Ames \& Archer, 1988; Nicholls, 1989; Pintrich, 2000). An important feature of mastery goals is that learning, understanding, and solving problems are ends in themselves (Duda \& Nicholls, 1992; Nicholls, 1983). In contrast, students with strong performance goals focus more on themselves, how they achieve compared to their classmates, and how they are perceived by others. Anderman and Maehr (1994) argue that that such a competitive environment inevitably produces winners and losers.

During the last two decades researchers have discriminated not only between mastery and performance goals, but also between approach and avoidance goals. Several researchers first discriminated between performance-approach and performance-avoidance goals (Elliot \& Harackiewicz, 1996; Middleton \& Midgley, 1997; Skaalvik, 1997; Skaalvik, Valås, \& Sletta, 1994), resulting in a trichotomous model of achievement goals. Performance-approach goals focus on demonstrating competence and achieving well relative to others whereas performance-avoidance goals focus on avoiding demonstrating incompetence or being negatively perceived by others (Skaalvik, 1997). Elliot (1999) further extended the model by discriminating between mastery-approach and mastery-avoidance goals. This led to a 2 x 2 framework of achievement goals. Students' goal orientations in mathematics classes were in this study conceptualized according to the trichotomous model. 
Previous studies consistently reveal that mastery goals are associated with adaptive behavioral and cognitive outcomes (e.g., Anderman \& Walters, 2006; Harackiewicz et al. 2002; Meece \& Miller, 2001; Wolters, 2004) whereas performance-avoidance goals are associated with less adaptive outcomes (Kaplan \& Maehr, 2007; Meece et al., 2006; Midgley \& Urdan, 2001; Skaalvik, 1997). Studies of performance-approach goals report more in consistent findings. However, several researchers report that it is related to a number of positive outcomes, for instance effort, persistence, and performance (Church, Elliot, \& Gable, 2001; Harackiewicz et al., 2002; Law, Elliot, \& Murayama, 2012-for an overview, see Senko, Hulleman, \& Harackiewicz, 2011). Nevertheless, performance-approach goals are controversial, for instance, an important issue is whether a performance-approach goal may turn into a performance-avoidance goal when the student encounters greater challenges. Exploring this prediction requires longitudinal studies.

\subsection{Mathematics Anxiety}

There is a lack of agreement among researchers about how to conceptualize mathematics anxiety. Researchers have emphasized different but overlapping reactions, for instance physical reactions (Posamentier \& Stepelman, 1986) and negative effect, worry, uneasiness and fear (D'Ailly \& Bergering, 1992; Wigfield \& Meece, 1988). These reactions can impede both learning and performance (Jain \& Dowson, 2009). There has also been a debate about the distinction between mathematics anxiety and test anxiety. In this study we conceptualize mathematics anxiety as an affective variable constituted by uneasiness and fear when working with mathematics. Thus, we distinguish mathematics anxiety from test anxiety which we do not include in this study.

Studies of both mathematics anxiety and test anxiety show that these constructs are negatively related to motivation and achievement (Hembree, 1988) and to students' self-beliefs, for instance mathematics self-concept and self-efficacy (Hembree, 1988; Jain \& Dowson, 2009; Schwarzer, \& Jerusalem, 1992; Schwarzer, Mueller, \& Greenglass, 1999; Skaalvik, 1997; Zeidner \& Matthews, 2005). Mathematics anxiety has also been shown to be predicted by performance-avoidance goal orientation, but not by mastery goal orientation or performance-approach goal orientation (Skaalvik, 1997). An interesting question for this study is if it is related to classroom goal structure, either directly or indirectly, through students' achievement goals. In a large scale study of fifth grade students in Singapore Lau and Nie (2008) found that a performance goal structure in mathematics classrooms positively predicted effort withdrawal and avoiding challenges in mathematics whereas a mastery goal structure negatively predicted these responses. A possible interpretation of these results is that a performance goal structure in mathematics classrooms increases mathematics anxiety among students.

\subsection{Help-Seeking Behavior}

According to Sakiz (2012), help-seeking behavior is a self-regulatory strategy comprised of cognitive, affective, motivational, and social aspects. Given that students face optimal and challenging tasks in mathematics, they most likely will experience difficulties and need guidance and feedback. Asking for help may therefore increase the value of instruction (Karabenick, 2004; Karabenick \& Sharma, 1994) and contribute to student learning (e.g., Nelson-LeGall \& Resnick, 1998; Newman, 1998, 2000, 2008; Ryan, Gheen, \& Midgley, 1998).

According to Karabenick (2004), the process of seeking help is inherently social. Help-seeking behavior may therefore be influenced by both the learning environment (e.g., classroom goal structure) and students' personal goal orientation. For instance, in a study of adults who had returned to high school E. Skaalvik \& S. Skaalvik (2005) found that both performance-avoidance and performance-approach goal orientation, but not mastery goal orientation, predicted the perception of help-seeking as threatening. A possible reason for this is that seeking help may be perceived as a demonstration of low competence, which is a particular concern for students with a strong performance orientation. As pointed out by Patrick et al., (2011) a mastery goal orientation will tend to decrease competence concerns regarding help-seeking as well as the actual help-seeking behavior, whereas a performance goal orientation will focus students on themselves and their competence relative to others. This goal orientation will therefore tend to increase competence concerns regarding help-seeking (see also Butler \& Neuman, 1995, Newman, 1994, 2002, 2004; Ryan \& Pintrich, 1997). Asking for help may therefore be experienced as an embarrassing situation, particularly by students with a strong performance orientation, because these students are preoccupied by how they are perceived by others. We therefore expect performance goals to be negatively related to help-seeking behavior and mastery goals to be positively related to help-seeking. Previous research often did not discriminate between performance-approach and performance-avoidance goals orientations. An important question for the present study was therefore to test if both these dimensions of performance goals were negatively related to help-seeking behavior. An interesting question was also if classroom goal structure predicts help-seeking behavior and if the relation is mediated through students' personal goal orientations. 


\section{Purpose of the Study and a Theoretical Model}

The purpose of the present study was to test a theoretical model of the relations between students' perceived goal structure, their personal goal orientation, mathematics anxiety, and help-seeking behavior. The theoretical model is based on the analyses and predictions presented above. Mastery goal structure was expected to be positively related to mastery goals and negatively related to performance-avoidance goals whereas performance goal structure was expected to be negatively related to mastery goals and positively related to both performance-approach and performance-avoidance goals. Additionally, performance-avoidance goals was expected to be positively related to mathematics anxiety and negatively related to help-seeking behavior whereas we expected mastery goals to be positively related to help-seeking behavior and negatively related to mathematics anxiety. Because research shows contradictory result for performance-approach goals we had no clear predictions regarding associations between this goal orientation and mastery goal structure, help-seeking behavior, or mathematics anxiety.

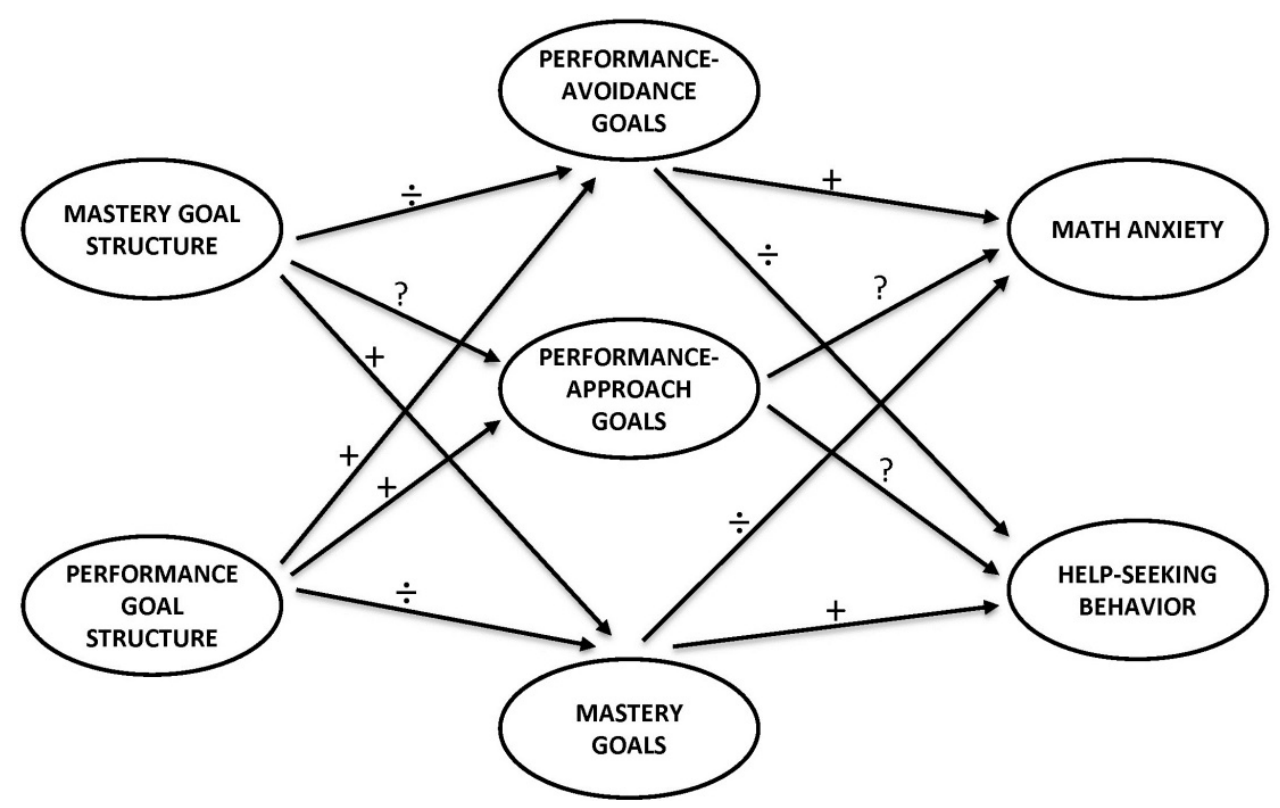

Figure 1. Hypothesized model of the relations between the constructs

\section{Method}

\subsection{Participants and Procedure}

Three hundred and nine students from two middle schools (8th-10th grade) located in one of the larger cities in Norway participated in the study. Thirty-four percent of the respondents attended ninth grade and sixty-six percent attended tenth grade. The sample consisted of forty-eight percent male students and fifty-two percent female students. The data were collected by means of a questionnaire administered in the school classes.

\subsection{Instruments}

Mastery goal structure was measured by means of six items whereas performance goal structure was measured by three items. Examples of items measuring mastery goal structure are: "My math teacher praises students if they improve themselves" and "My math teacher praises students if they do the best they can". The scale had a Cronbach's alpha of .89. Examples of items measuring performance goal structure are: "My math teacher praises only the best students", and "My math teacher only cares about the best students". Cronbach's alpha for the scale was 79 .

The students' personal goal orientations were measured by a 14 -item goal orientation scale. The items were modified from the general School Goal Orientation Scale (Skaalvik, 1997) to focus on mathematics. Mastery orientation was measured by six items. Examples of items are: "In mathematics it is important for me to learn something new", and "In mathematics I try to understand the problems I am working with". Cronbach's alpha for the scale was .90. Performance-approach orientation was measured by four items, for instance: "In mathematics I 
try to do better than other students in my class" and "In mathematics, I try to manage tasks that other students do not manage". Cronbach's alpha for the scale was .92. Performance-avoidance orientation was also measured by four items. Examples of items are: "In mathematics, it is important for me to avoid looking stupid" and "The worst thing about doing a mistake in mathematics class is that other students may notice". Cronbach's alpha for the scale was .88 .

We measured math anxiety by means of a five-item scale. Examples of items are: "I am afraid to make a fool of myself in math lessons", and "When I am working with math I get so nervous that I can't think straight". The scale had a Cronbach's alpha of .89 .

To what extent the students seek help was tapped by four items. The instrument was derived from a previous study of help-seeking in mathematics (E. Skaalvik \& S. Skaalvik, 2013b) and had a Cronbach's alpha of .88. Examples of items measuring help-seeking behavior are: "If there is something I do not understand in math, I ask the teacher for help" and, "If I am working on a math problem that I am not able to solve, I ask the teacher for advice".

Responses for all items were given on a six-point scale ranging from "Absolutely disagree" (1) to "Absolutely agree" (6).

\subsection{Data Analysis}

We initially conducted a confirmatory factor analysis (CFA) of a measurement model consisting of all constructs in the study. Then, we investigated the hypothesized relations between the variables by means of structural equation modeling (SEM).The covariance matrix is usually the foundation for such analyses. When conducting SEM, the analysis produces an estimated population covariance matrix based on the model specified. A key element of SEM is to assess whether the model produces an estimated matrix that is consistent with the sample matrix. This consistency is investigated through different measures of goodness of fit statistics such as CFI, IFI, TLI, RMSEA, and the chi-square test (Hoyle, 2012; Kline, 2011; Tabachnick \& Fidell, 2007). For the CFI, IFI, and TLI indices, values above .90 are typically considered as acceptable, whereas values greater than .95 indicate a good fit (Hoyle, 2012; Hu \& Bentler, 1999; Kline, 2011). For well-specified models, an RMSEA of .06 or less reflects a good fit (Byrne, 2010; Tabachnick \& Fidell, 2007).

\section{Results}

\subsection{Correlations and Descriptive Statistics}

Table 1 shows correlations and descriptive statistics of the study variables. Mastery goal structure was moderately and negatively related to performance goal structure. It was also positively related to mastery goal orientation but not significantly related to performance-avoidance or performance-approach orientation. Moreover, it was positively related to help-seeking behavior but not significantly related to mathematics anxiety. Performance goal structure was positively related to performance-avoidance orientation but not significantly related to performance-approach orientation. Performance goal structure was also negatively related to mastery orientation and to help-seeking behavior and positively related to mathematics anxiety. Performance-avoidance orientation was strongly and positively related to mathematics anxiety; mastery orientation was negatively related to anxiety, whereas performance-approach orientation was not significantly related to anxiety. Also help-seeking behavior was positively related to mastery goal structure and mastery orientation and negatively related to performance goal structure and performance-avoidance orientation. Interestingly, performance-approach orientation was weakly but positively related to help-seeking behavior. 
Table 1. Correlations and descriptive statistics of the study variables

\begin{tabular}{llllllll}
\hline Variable & 1 & 2 & 3 & 4 & 5 & 6 & 7 \\
\hline 1. Mastery goal structure & - & & & & & & \\
2. Performance goal structure & $-.457^{* *}$ & - & & & & & \\
3. Performance-avoidance goals & -.090 & $.315^{* *}$ & - & & & & \\
4. Performance approach goals & .082 & .059 & $.259^{* *}$ & - & & & \\
5. Mastery goals & $.429^{* *}$ & $-.360^{* *}$ & $-.126^{*}$ & $.279^{* *}$ & - & & \\
6. Math anxiety & -.092 & $.303^{* *}$ & $.679^{* *}$ & .029 & $-.203^{* *}$ & - & \\
7. Help-seeking behavior & $.239^{* *}$ & $-.277^{* *}$ & $-.278^{* *}$ & $.123^{*}$ & $.475^{* *}$ & $-.332^{* *}$ & - \\
\hline Maximum possible score & 36 & 18 & 24 & 24 & 36 & 30 & 24 \\
Number of items & 6 & 3 & 4 & 4 & 6 & 5 & 4 \\
Mean & 25.63 & 7.55 & 10.83 & 11.33 & 26.33 & 10.95 & 18.33 \\
Standard deviation & 6.83 & 3.88 & 5.88 & 6.05 & 6.70 & 6.46 & 5.11 \\
Cronbach's alpha & .89 & .79 & .88 & .92 & .90 & .89 & .88 \\
\hline
\end{tabular}

Note. $* p<.05, * * p<.01, * * * p<.001$. Based on observed variables.

\subsection{Measurement Model}

A confirmatory factor analysis was conducted to investigate the measurement model. The model included the students' perceived goal structures, goal orientations, mathematics anxiety, and help-seeking behavior. None of the error variances were allowed to correlate. The model had acceptable fit to data $\left(\chi^{2}(443, \mathrm{~N}=309)=979.21, \mathrm{p}\right.$ $<.001, \mathrm{CMIN} / \mathrm{DF}=2.210, \mathrm{RMSEA}=0.063, \mathrm{IFI}=0.921, \mathrm{TLI}=0.910$, and $\mathrm{CFI}=0.920)$. All factor loadings were significant at $\mathrm{p}<.001$. Supporting the zero-order correlations the correlations between the latent variables varied from low to moderate (see Table 2). The result from the CFA supports a model of seven separate, but correlated constructs.

Table 2. Correlations between the latent variables in the model

\begin{tabular}{llllllll}
\hline Variable & 1 & 2 & 3 & 4 & 5 & 6 & 7 \\
\hline 1. Mastery goal structure & - & & & & & \\
2. Performance goal structure & $-.567^{* * *}$ & - & & & & \\
3. Performance-avoidance goals & -.046 & $.322^{* * *}$ & - & & & \\
4. Performance-approach goals & $.134^{*}$ & .066 & $.328^{* * *}$ & - & & & \\
5. Mastery goals & $.481^{* * *}$ & $-.407^{* * *}$ & $-.131^{*}$ & $.310^{* * *}$ & - & & \\
6. Math anxiety & -.064 & $.349^{* * *}$ & $.725^{* * *}$ & .060 & $-.240^{* * *}$ & - & \\
7. Help-seeking behavior & $.299^{* * *}$ & $-.253^{* * *}$ & $-.221^{* * *}$ & $.158^{*}$ & $.512^{* * *}$ & $-.275^{* * *}$ & - \\
\hline
\end{tabular}

Note. ${ }^{*} p<.05, * * p<.01, * * * p<.001$.

\subsection{Structural Model}

We tested the theoretical model displayed in Figure 1by means of structural equation modeling. The model had acceptable fit to the data $\left(\chi^{2}(452, \mathrm{~N}=309)=1045.42, \mathrm{p}<.001, \mathrm{CMIN} / \mathrm{DF}=2.313\right.$, RMSEA $=0.065$, IFI $=$ 0.912 , TLI $=0.903$, and CFI $=0.911$ ). Estimates of the standardized regression weights and the squared multiple correlations are shown in Figure 2, whereas unstandardized regression weights, standard errors, total effects, and indirect effects are presented in Table 3. The initial analysis showed that some of the relations between the variables were not significant $(\mathrm{p}<.05)$. These regression coefficients are not included in Figure 2. 


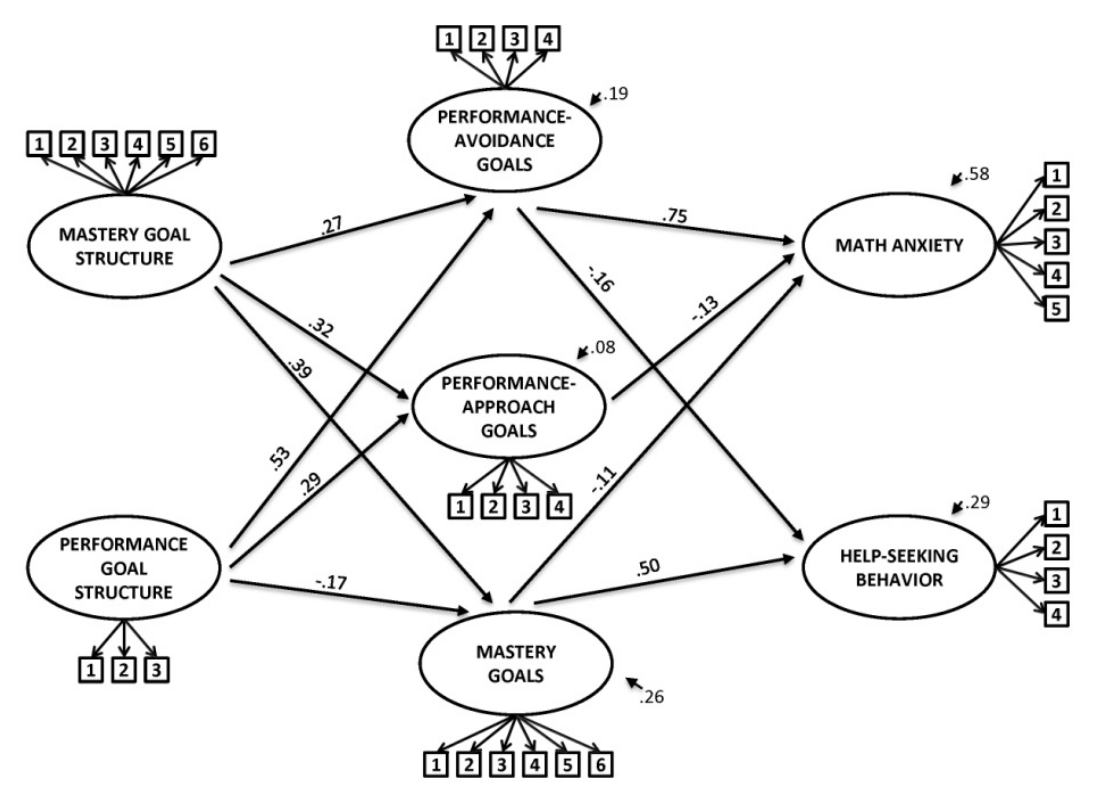

Figure 2. Structural model of the relations between the constructs

Table 3. Summary of SEM analysis of the theoretical model

\begin{tabular}{|c|c|c|c|c|}
\hline Latent variable & $\begin{array}{l}\text { Unstandardized regression } \\
\text { weights }\end{array}$ & SE & $\begin{array}{l}\text { Standardized total } \\
\text { effect }\end{array}$ & $\begin{array}{l}\text { Standardized } \\
\text { indirect effect }\end{array}$ \\
\hline \multicolumn{5}{|l|}{ Performance-avoidance goals } \\
\hline Mastery goal structure & $.281 * *$ & .091 & .268 & - \\
\hline Performance goal structure & $.701^{* * *}$ & .140 & .533 & - \\
\hline \multicolumn{5}{|l|}{ Performance-approach goals } \\
\hline Mastery goal structure & $.346^{* * *}$ & .091 & .318 & - \\
\hline Performance goal structure & $.395^{* *}$ & .127 & .290 & - \\
\hline \multicolumn{5}{|l|}{ Mastery goals } \\
\hline Mastery goal structure & $.413 * * *$ & .079 & .393 & - \\
\hline Performance goal structure & $-.224 *$ & .107 & -.171 & - \\
\hline \multicolumn{5}{|l|}{ Math anxiety } \\
\hline Mastery goal structure & - & - & .117 & .117 \\
\hline Performance goal structure & - & - & .379 & .379 \\
\hline Performance-avoidancegoals & $.764 * * *$ & .069 & .749 & - \\
\hline $\begin{array}{l}\text { Performance-approach } \\
\text { goals }\end{array}$ & $-.130 * *$ & .045 & -.132 & - \\
\hline Mastery goals & $-.107 *$ & .047 & -.105 & - \\
\hline \multicolumn{5}{|l|}{ Help-seeking behavior } \\
\hline Mastery goal structure & - & - & .152 & .152 \\
\hline Performance goal structure & - & - & -.172 & -.172 \\
\hline $\begin{array}{l}\text { Performance-avoidance } \\
\text { goals }\end{array}$ & $-.153^{* *}$ & .050 & -.164 & - \\
\hline
\end{tabular}




\begin{tabular}{|c|c|c|c|c|}
\hline $\begin{array}{l}\text { Performance-approach } \\
\text { goals }\end{array}$ & - & - & - & - \\
\hline Mastery goals & $.464^{* * *}$ & .052 & 497 & - \\
\hline
\end{tabular}

Mastery goal structure was positively related to mastery orientation (.39) as well as to performance-approach orientation (.32) and performance-avoidance orientation (.27). Performance goal structure was also positively related to performance- approach orientation (.29) and performance-avoidance orientation (.53) and negatively related to mastery orientation (-.17). The positive relation between performance goal structure and performance-avoidance orientation was relatively strong whereas the negative relation between performance goal structure and mastery orientation was weak. Mastery orientation was positively related to help-seeking behavior (.50) and negatively related to mathematics anxiety (-.11). Performance-approach orientation was weakly but negatively related to mathematics anxiety (-.13) and not significantly related to help-seeking behavior. Performance-avoidance orientation was positively and strongly related to mathematics anxiety (.75) and negatively but weakly related to help-seeking behavior (-.16).

The SEM analysis showed no significant direct relations between classroom goal structure and mathematics anxiety or help-seeking behavior. Table 3 shows small positive indirect effects of mastery goal structure on mathematics anxiety (.12) and help-seeking behavior (.15). An inspection of Figure 2 shows negative indirect effects of mastery goal structure on mathematics anxiety mediated through mastery orientation and performance-approach orientation whereas the indirect effect mediated through performance-avoidance orientation was positive. On help-seeking behavior we found a positive indirect effect of mastery goal structure mediated through mastery orientation and a negative indirect effect mediated through performance-avoidance orientation. Table 3 also shows a moderate and positive indirect effect of performance goal structure on mathematics anxiety (.38) and a small and negative indirect effect on help-seeking behavior (-.17).

\section{Discussion}

The present study explored a trichotomous model of personal goal orientation consisting of mastery goals, performance-approach goals, and performance-avoidance goals. Supporting our predictions mathematics anxiety was positively and strongly predicted by performance-avoidance goals and negatively but weakly by mastery goals. Also supporting our predictions help-seeking behavior was positively and quite strongly predicted by mastery goals and negatively but weakly by performance-avoidance goals. Performance-approach goals were weakly and negatively related to mathematics anxiety whereas this dimension of performance goals did not significantly predict help-seeking behavior.

These results add to a number of studies showing that mastery goals are associated with adaptive motivational and behavioral responses, in this case lower levels of anxiety and adaptive help-seeking behavior, whereas performance-avoidance goals are associated with less adaptive outcomes, particularly higher levels of mathematics anxiety (e.g., Anderman \& Wolters, 2006; Harackiewicz et al., 2002; Kaplan \& Maehr, 2007; Meece \& Miller, 2001; Wolters, 2004). As noted in the introduction previous research on performance-approach goals shows inconsistent results. In this study the SEM analysis did not reveal any significant association between performance-approach goals and help-seeking behavior whereas it showed a week tendency that performance-approach goals were associated with lower levels of mathematics anxiety.

A practical implication of these results is that teachers should strive to develop mastery goal orientation among students and avoid the development of performance-avoidance goals. Our interpretation is that teachers also should avoid practices that foster performance-approach goals. There are two reasons for this. Firstly, although performance-approach goals in this study did not predict lower levels of help-seeking behavior or higher levels of anxiety, this goal orientation was not strongly related to positive motivational outcomes. Secondly, the positive correlation between performance-approach and performance-avoidance goals indicate that performance-approach goals may change into performance-avoidance goals when students meet more demanding challenges. Our results clearly indicate that such a change might be followed by less adaptive motivational and behavioral responses.

This study also adds to our understanding of how classroom goal structure is related to students' achievement goals, math anxiety, and learning strategies. As could be predicted by theory and previous research a mastery goal structure was positively related to mastery goals whereas a performance goal structure was positively related to both performance-approach and performance-avoidance goals (see Lou, Hogan, \& Paris, 2011; Urdan, 
2004; Urdan \& Midgley, 2003). The relation between a performance goal structure and performance-avoidance personal goals was particularly strong. Also, in accordance with expectations a performance goal structure predicted lower levels of mastery goals. These findings should be emphasized because they clearly demonstrate that one should make an effort to avoid creating a performance goal structure in school.

However, contrary to theoretical expectations, a mastery goal structure was positively related to both performance-approach and performance-avoidance goals. This result also contradicts previous findings in research on teachers. E. Skaalvik and S. Skaalvik (2013a) found that mastery goal structure was negatively related to performance-avoidance goals and not significantly related to performance-approach goals among teachers. A possible explanation of the present study may be that even in classrooms where teachers focus on learning and improvement (mastery goal structure) the students may perceive a strong emphasis on achievement. As discussed in the introduction, students' achievements are recognized in different ways in classrooms characterized by a mastery goal structure and in classrooms characterized by a performance goal structure. Whereas a performance goal structure means that achievement is recognized as doing better that others a mastery goal structure means that achievement is recognized as understanding and improvement. However, the present study indicates that in both these goal structures the messages perceived by the students may be that achievement is important and valued. This may foster performance goals among some of the students. Therefore, the relations between classroom goal structure and students' goal orientation may be more complex than previously assumed. An important task for future research should therefore be to explore for which students and under what conditions a mastery goal structure promotes performance orientation.

Previous research has shown that a mastery goal structure is associated with several adaptive outcomes, for instance adaptive learning strategies, whereas a performance goal structure is associated with less adaptive outcomes (e.g., Patrick et al., 2011; Walker, 2012; Wolters, 2004). Interestingly, the results of the present study revealed no significant direct relations between classroom goal structure and help-seeking behavior or mathematic anxiety. The relations with classroom goal structure were indirect, mediated through personal goal orientation. As shown in Table 3 the indirect effect of a mastery goal structure on help-seeking behavior was positive whereas the indirect effect of a performance goal structure was negative. However, an inspection of Figure 2 reveals two different indirect effects of a mastery goal structure: a positive effect mediated through mastery goal orientation and a negative effect mediated through performance-avoidance goal orientation. The former of these effects were the strongest resulting in a positive total indirect effect. The negative effect mediated through performance-avoidance goal orientation further demonstrates the need to explore for which students and under what conditions a mastery goal structure promotes performance-avoidance orientation.

Also, Figure 2 shows a positive indirect effect of mastery goal structure on anxiety that is mediated through performance-avoidance goal orientation and negative effects mediated through mastery goal orientation and performance-approach orientation. Similarly, Figure 2 shows different indirect effects of a performance goal structure. A particularly large indirect effect of performance goal structure on mathematics anxiety was mediated through performance-avoidance goals. These results strongly indicate that a performance classroom goal structure should be avoided because it is predictive both of higher anxiety and lower levels of help-seeking behavior.

As noted above, an important question for future research is for which students and under what conditions a mastery goal structure promotes performance orientation among students. Future research should also explore associations between mathematics classroom goal structure and a variety of students' cognitive, motivational and behavioral responses, for instance intrinsic and extrinsic motivation for mathematics, mathematics task values, mathematics self-efficacy, and motivation for choosing mathematic in higher education.

The present study has some limitations. One limitation is that the study was conducted as cross-sectional survey. Such data do not support analyses in causal terms, even though our interpretations are based on previous findings and theoretical analyses. Longitudinal studies of the same and additional constructs are called for. Also, only two schools participated in the study. Future research should increase the number of schools, grades and participants. Finally, our proposed model should be tested in other contexts and cultures.

\section{References}

Ames, C. (1992). Achievement goals and the classroom motivational climate. In D. H. Schunk, \& J. L. Meece (Eds.), Student perception in the classroom (pp. 327-348). Hillsdale, NJ: Erlbaum.

Ames, C., \& Archer, J. (1988). Achievement Goals in the Classroom-Students Learning-Strategies and Motivation Processes. Journal of Educational Psychology, 80, 260-267. http://dx.doi.org/10.1037/0022-0663.80.3.260 
Anderman, E. M., \& Maehr, M. L. (1994). Motivation and Schooling in the Middle Grades. Review of Educational Research, 64, 287-309. http://dx.doi.org/10.3102/00346543064002287

Anderman, E. M., \& Wolters, C. A. (2006). Goals, values, and affect: Influences on student motivation. In P. Alexander, \& P. Winne (Eds.), Handbook of educational psychology. Mahwah, NJ: Earlbaum.

Butler, R., \& Neuman, O. (1995). Effects of task and ego achievement goals on help-seeking behaviors and attidudes. Journal of Educational Psychology, 87, 261-267. http://dx.doi.org/10.1037/0022-0663.87.2.261

Butler, R., \& Shibaz, L. (2008). Achievement goals for teaching as predictors of students' perceptions of instructional practices and students' help seeking and cheating. Learning and Instruction, 18(5), 453-467. http://dx.doi.org/10.1016/j.learninstruc.2008.06.004

Byrne, B. M. (2010). Structural equation modeling with AMOS: basic concepts, applications, and programming. New York: Routledge.

Church, M. A., Elliot, A. J., \& Gable, S. L. (2001). Perceptions of classroom environment, achievement goals, and achievement outcomes. Journal of Educational Psychology, 93, 43-54. http://dx.doi.org/10.1037/0022-0663.93.1.43

D’Ailly, H., \& Bergering, A. (1992). Mathematics anxiety and mathematics avoidance behavior: A validation study of two MARS factor-derived scales. Education and Psychological Measurement, 52, 369-377. http://dx.doi.org/10.1177/0013164492052002012

Duda, J. L., \& Nicholls, J. G. (1992). Dimensions of achievement motivation in schoolwork and sport. Journal of Educational Psychology, 84, 290-299. http://dx.doi.org/10.1037/0022-0663.84.3.290

Elliot, A. J. (1999). Approach and avoidance motivation and achievement goals. Educational Psychologist, 34, 169-189. http://dx.doi.org/10.1207/s15326985ep3403_3

Elliot, A. J., \& Harackiewicz, J. M. (1996). Approach and avoidance achievement goals and intrinsic motivation: A mediational analysis. Journal of Personality and Social Psychology, 70(3), 461-475. http://dx.doi.org10.1037/0022-3514.70.3.461

Harackiewicz, J. M., Barron, K. E., Pintrich, P. R., Elliot, A. J., \& Thrash, T. M. (2002). Revision of achievement goal theory: Necessary and illuminating. Journal of Educational Psychology, 94, 638-645. http://dx.doi.org/10.1037/0022-0663.94.3.638

Hembree, R. (1988). Correlations, causes and treatment of test anxiety. Review of Educational Research, 58, 47-77. http://dx.doi.org/10.3102/00346543058001047

Hoyle, R. H. (2012). Handbook of structural equation modeling. New York: Guilford press.

Hu, L.-T., \& Bentler, P. M. (1999). Cutoff criteria for fit indexes in covariance structure analysis: Conventional criteria versus new alternatives. Structural Equation Modeling, 6, 1-55. http://dx.doi.org/10.1080/10705519909540118

Jain, S., \& Dowson, M. (2009). Mathematics anxiety as a function of multidimensional self-regulation and $\begin{array}{lllll}\text { self-efficacy. } \quad \text { Contemporary } & \text { Educational }\end{array}$ http://dx.doi.org/10.1016/j.cedpsych.2009.05.004

Kaplan, A., \& Maehr, M. (2007). The Contributions and Prospects of Goal Orientation Theory. Educational Psychology Review, 19, 141-184. http://dx.doi.org/10.1007/s10648-006-9012-5

Karabenick, S. A. (2004). Perceived achievement goal structure and college student help seeking. Journal of Educational Psychology, 96, 569-581. http://dx.doi.org/10.1037/0022-0663.96.3.569

Karabenick, S. A., \& Sharma, R. (1994). Perceived Teacher Support of Student Questioning in the College Classroom-Its Relation to Student Characteristics and Role in the Classroom Questioning Process. Journal of Educational Psychology, 86, 90-103. http://dx.doi.org/10.1037/0022-0663.86.1.90

Kline, R. B. (2011). Principles and practice of structural equation modeling. New York: Guilford Press.

Lau, S., \& Nie, Y. (2008). Interplay between personal goals and classroom goal structures in predicting student outcomes: A multilevel analysis of person-context interactions. Journal of Educational Psychology, 100, 15-29. http://dx.doi.org/10.1037/0022-0663.100.1.15

Lavasani, M. G., Hejazi, E., \& Varzaneh, J. Y. (2011). The predicting model of math anxiety: The role of classroom goal structure, self-regulation and math self-efficacy. Procedia-Social and Behavioral Sciences, 15, 557-562.http://dx.doi.org/10.1016/j.sbspro.2011.03.141 
Law, W., Elliot, A. J., \& Murayama, K. (2012). Perceived competence moderates the relation between performance-approach and performance-avoidance goals. Journal of Educational Psychology, 104, 806-819. http://dx.doi.org10.1037/a0027179

Luo, W., Hogan, D., \& Paris, S. G. (2011). Predicting Singapore students' achievement goals in their English study: Self-construal and classroom goal structure. Learning and Individual Differences, 21, 526-535. http://dx.doi.org/10.1016/j.lindif.2011.07.002

Meece, J. L., \& Miller, S. D. (2001). A Longitudinal Analysis of Elementary School Students' Achievement Goals in Literacy Activities. Contemporary Educational Psychology, 26, 454-480. http://dx.doi.org:10.1006/ceps.2000.1071

Meece, J. L., Anderman, E. M., \& Anderman, L. H. (2006). Classroom goal structure, student motivation, and academic achievement. Annual Review of Psychology, 57, 487-503. http://dx.doi.org/10.1146/annurev.psych.56.091103.070258

Meier, A., Reindl, M., Grassinger, R., Berner, V. D., \& Dresel, M. (2013). Development of achievement goals across the transition out of secondary school. International Journal of Educational Research, 61, 15-25. http://dx.doi.org/10.1016/j.jijer.2013.03.006

Middleton, M. J., \& Midgley, C. (1997). Avoiding the demonstration of lack of ability: An underexplored aspect $\begin{array}{llll}\text { of goal theory. Journal of Educational Psychology, 89, } & \text { 710-718. }\end{array}$ http://dx.doi.org/10.1037/0022-0663.89.4.710

Midgley, C., \& Urdan, T. (2001). Academic self-handicapping and achievement goals: A further examination. Contemporary Educational Psychology, 26, 61-75. http://dx.doi.org10.1006/ceps.2000.1041

Nelson-LeGall, S., \& Resnick, L. (1998). Help-seeking, achievement motivation and the social practice of intelligence in school. In S. A. Karabenick (Ed.), Strategic help-seeking. Implications for learning and teaching. (pp. 13-37). Mahwah, NJ: Lawrence Erlbaum Ass.

Newman, R. S. (1994). Adaptive help seeking: A strategy of self-regulated learning. In D. Schunk \& B. Zimmerman (Eds.), Self-regulation of Learning and Performance: Issues and Educational Applications (pp. 283-301). Hillside, NJ, Lawrence ErlbaumAssociates.

Newman, R. S. (1998). Adaptive help-seeking: A role of social interaction in self-regulated learning. In S. A. Karabenick (Ed.), Strategic help-seeking. Implications for learning and teaching (pp. 13-37). Mahwah, NJ: Lawrence Erlbaum Ass.

Newman, R. S. (2000). Social Influences on the Development of Children's Adaptive Help Seeking: The Role of Parents, Teachers, and Peers. Developmental Review, 20,350-404. http://dx.doi.org/10.1006/drev.1999.0502

Newman, R. S. (2002). How Self-Regulated Learners Cope with Academic Difficulty: The Role of Adaptive Help Seeking. Theory Into Practice, 41, 132-138. http://dx.doi.org/10.1207/s15430421tip4102_10

Newman, R. S. (2008). The motivational role of adaptive help seeking in self-regulated learning. In D. H. Schunk, \& B. J. Zimmerman (Eds.), Motivation and self-regulated learning: Theory, research, and applications (pp. 15-337). New York, NY: Lawrence Erlbaum.

Nicholls, J. G. (1983). Conceptions of ability and achievement motivation: a theory and its implications for education. In S. G. Paris, G. M. Olson, \& H. W. Stevenson (Eds.), Learning and motivation in the classroom (pp. 211-237). Hillsdale, New Jersey: Lawrence Erlbaum Ass.

Nicholls, J. G. (1989). The competitive ethos and democratic education. Cambridge, MA: Harvard University Press.

Nolen, S. B., \& Haladyna, T. M. (1990). Personal and environmental influences on students' beliefs about effective study strategies. Contemporary Educational Psychology, 15, 116-130. http://dx.doi.org/10.1016/0361-476X(90)90011-O

Patrick, H., Kaplan, A., \& Ryan, A. M. (2011). Positive Classroom Motivational Environments: Convergence Between Mastery Goal Structure and Classroom Social Climate. Journal of Educational Psychology, 103, 367-382. http://dx.doi.org/10.1037/a0023311

Pintrich, P. R. (2000). Multiple goals, multiple pathways: The role of goal orientation in learning and $\begin{array}{lllll}\text { achievement. Journal of Educational Psychology, } & \text { 92, }\end{array}$ http://dx.doi.org10.1037/0022-0663.92.3.544 
Polychroni, F., Hatzichristou, C., \& Sideridis, G. (2012). The role of goal orientations and goal structures in explaining classroom social and affective characteristics. Learning and Individual Differences, 22, 207-217. http://dx.doi.org/10.1016/j.lindif.2011.10.005

Posamentier, A. S., \& Stepelman, J. (1986). Teaching Secondary School Mathematics (2nd ed.). Columbus, Ohio: Merrill.

Roeser, R. W., Midgley, C., \& Urdan, T. C. (1996). Perception of the school psychological environment and early adolescents' psychological and behavioral functioning in school: The mediating role of goals and belonging. Journal of Educational Psychology, 88, 408-422. http://dx.doi.org/10.1037/0022-0663.88.3.408

Ryan, A. M., \& Pintrich, P. R. (1997). Should I ask for help?: The role of motivation and attitudes in adolescents' help seeking in math class. Journal of Educational Psychology, 89, 329-341. http://dx.doi.org/10.1037/0022-0663.89.2.329

Ryan, A. M., Gheen, M. H., \& Midgley, C. (1998). Why Do Some Students Avoid Asking for Help? An Examination of the Interplay among Students' Academic Efficacy, Teachers' Social-Emotional Role, and the Classroom Goal Structure. Journal of Educational Psychology, 90, 528-535. http://dx.doi.org/10.1037/0022-0663.90.3.528

Sakiz, G. (2012). Perceived instructor affective support in relation to academic emotions and motivation in college. Educational Psychology, 32, 63-79. http://dx.doi.org/10.1080/01443410.2011.625611

Schwarzer, R., \& Jerusalem, M. (1992). Advances in anxiety theory: A cognitive process approach. In K. A. Hagtvet, \& T. B. Johnsen (Eds.), Advances in Test Anxiety Research (Vol. 7, pp. 2-31). Lisse: Swets \& Zeitlinger.

Schwarzer, R., Mueller, J., \& Greenglass, E. (1999). Assessment of perceived general self-efficacy on the internet: Data collection on cyberspace. Anxiety, stress, \& Coping: An international Journal, 12, 145-161. http://dx.doi.org/10.1080/10615809908248327

Senko, C., Hulleman, C. S., \& Harackiewicz, J. M. (2011). Achievement Goal Theory at the Crossroads: Old Controversies, Current Challenges, and New Directions. Educational Psychologist, 46, 26-47. http://dx.doi.org10.1080/00461520.2011.538646

Skaalvik, E. M. (1997). Self-enhancing and self-defeating ego orientation: Relations with task and avoidance orientation, achievement, self-perceptions, and anxiety. Journal of Educational Psychology, 89, 71-81. http://dx.doi.org/10.1037/0022-0663.89.1.71

Skaalvik, E. M., \& Skaalvik, S. (2005). Self-concept, motivational orientation, and help-seeking behavior in mathematics: A study of adults returning to high school. Social Psychology of Education, 8, 285-302. http://dx.doi.org/10.1007/s11218-005-3276-3

Skaalvik, E. M., \& Skaalvik, S. (2013a). Teachers' perceptions of the school goal structure: Relations with teachers' goal orientations, work engagement, and job satisfaction. International Journal of Educational Research, 62, 199-209. http://dx.doi.org/10.1016/j.ijer.2013.09.004

Skaalvik, E. M., \& Skaalvik, S. (2013b). School goal structure: Associations with students' perceptions of their teachers as emotionally supportive, academic self-concept, intrinsic motivation, effort, and help seeking behavior. International Journal of Educational Research, 61, 5-14. http://dx.doi.org/10.1016/j.ijer.2013.03.007

Skaalvik, E. M., Valåns, H., \& Sletta, O. (1994). Task Involvement and Ego Involvement: relations with academic achievement, academic self-concept and self-esteem. Scandinavian Journal of Educational Research, 38, 231-243. http://dx.doi.org10.1080/0031383940380306

Sproule, J., Wang, C. K. J., Morgan, K., McNeill, M., \& Mcmorris, T. (2007). Effects of motivational climate in Singaporean physical education lessons on intrinsic motivation and physical activity intention. Personality and Individual Differences, 43, 1037-1049. http://dx.doi.org/10.1016/j.paid.2007.02.017

Tabachnick, B. G., \& Fidell, L. S. (2007). Using multivariate statistics. Boston: Pearson/Allyn and Bacon.

Urdan, T. (2004). Predictors of Academic Self-Handicapping and Achievement: Examining Achievement Goals, Classroom Goal Structures, and Culture. Journal of Educational Psychology, 96, 251-264. http://dx.doi.org10.1037/0022-0663.96.2.251

Urdan, T., \& Midgley, C. (2003). Changes in the perceived classroom goal structure and pattern of adaptive learning during early adolescence. Contemporary Educational Psychology, 28, 524-551. 
http://dx.doi.org/10.1016/S0361-476X(02)00060-7

Urdan, T., \& Schoenfelder, E. (2006). Classroom effects on student motivation: Goal structures, social relationships, and competence beliefs. Journal of School Psychology, 44, 331-349. http://dx.doi.org/10.1016/j.jsp.2006.04.003

Urdan, T., \& Turner, J. C. (2005). Competence motivation in the classroom. In A. E. Elliot, \& C. Dweck (Eds.), Handbook of Competence Motivation (pp. 297-317). New York: Guilford.

Walker, C. (2012). Student perceptions of classroom achievement goals as predictors of belonging and content instrumentality. Social Psychology of Education, 15, 97-107. http://dx.doi.org/10.1007/s11218-011-9165-z

Wigfield, A., \& Meece, J. L. (1988). Math anxiety in elementary and secondary school students. Journal of Educational Psychology, 80, 210-216. http://dx.doi.org/10.1037/0022-0663.80.2.210

Wolters, C. A. (2004). Advancing Achievement Goal Theory: Using Goal Structures and Goal Orientations to Predict Students' Motivation, Cognition, and Achievement. Journal of Educational Psychology, 96, 236-250. http://dx.doi.org/10.1037/0022-0663.96.2.236

Zeidner, M., \& Metthews, G. (2005). Evaluation anxiety. Current theory and research. In A. J. Elliot, \& C. S. Dweck (Eds.), Handbook of Competence and Motivation (pp. 141-163). New York: The Guilford Fress.

\section{Copyrights}

Copyright for this article is retained by the author(s), with first publication rights granted to the journal.

This is an open-access article distributed under the terms and conditions of the Creative Commons Attribution license (http://creativecommons.org/licenses/by/3.0/). 